\title{
DNM2 wt Allele
}

National Cancer Institute

\section{Source}

National Cancer Institute. DNM2 wt Allele. NCI Thesaurus. Code C102797.

Human DNM2 wild-type allele is located in the vicinity of 19p13.2 and is approximately $118 \mathrm{~kb}$ in length. This allele, which encodes dynamin-2 protein, is involved in both microtubule polymerization and GT Pase activity. Mutation of the gene is associated with centronuclear myopathy type 1 and Charcot-Marie-T ooth disease types dominant intermediate $\mathrm{B}$ and $2 \mathrm{M}$ axonal. 